\title{
Statistical Analysis on Physico-Chemical Properties of Some Nigerian Clay Deposits
}

\author{
Jongs Solomon Lydia' ${ }^{1}$ Jock Asanja Alexander ${ }^{*}{ }^{\oplus}$, Ekanem Eno Okon ${ }^{3}$, Jauro Aliyu ${ }^{3}$ \\ ${ }^{1}$ National Metallurgical Development Centre, Jos, Nigeria \\ ${ }^{2}$ Chemical \& Petroleum Techniques, Department of Science Laboratory Technology, University of Jos, Jos, Nigeria \\ ${ }^{3}$ Department of Chemistry, Abubakar Tafawa Balewa University, Bauchi, Nigeria \\ Email: *alsanja@gmail.com
}

How to cite this paper: Lydia, J.S., Alexander, J.A., Okon, E.E. and Aliyu, J. (2019) Statistical Analysis on Physico-Chemical Properties of Some Nigerian Clay Deposits. Journal of Materials Science and Chemical Engineering, 7, 52-63.

https://doi.org/10.4236/msce.2019.78007

Received: July 10, 2019

Accepted: August 19, 2019

Published: August 22, 2019

Copyright (C) 2019 by author(s) and Scientific Research Publishing Inc. This work is licensed under the Creative Commons Attribution International License (CC BY 4.0).

http://creativecommons.org/licenses/by/4.0/

\begin{abstract}
Clays are among the most essential industrial minerals due to their unique physicochemical properties and versatile usage. This paper used Statistical Package for Social Sciences (SPSS) software to characterize five clay deposits for their physical and chemical compositions. The package, was employed to carry out the Analysis of Variance (ANOVA) by Post-Hoctambane multiple comparisons and Kristal Wallis at 5\% confidence level for the $\mathrm{f}$ - and t-tests respectively. The analysis of variance of the chemical components of the samples by post-hoc $\left(\mathrm{f}_{8}, 36=52.40, \mathrm{p}<0.05\right)$ showed that significant difference exist between the average concentration means. While the Kristal Wallis one sample t-test $\left(\mathrm{T}_{8}, 37.38\right.$ and $\left.\mathrm{p}<0.05\right)$ showed a great degree of significant difference in the p-values of the means of $\mathrm{SiO}_{2}$ and $\mathrm{Al}_{2} \mathrm{O}_{3}$. Pearson bivariate correlation statistical tool was also used to establish if significant positive interrelationships exist between the parameters in each site of the clay samples at $(\mathrm{p}<0.01$ and $\mathrm{p}<0.05)$. The result of the correlation indicates a very significant, strong and positive coefficient $\mathrm{p}$-values above 0.900 between the chemical and physicalproperties. Pearson bivariate correlation coefficient between the chemical and physical parameters of the clay samples indicates very significant, strong and positive correlations with $\mathrm{p}$-values above 0.900 at $(\mathrm{p}<$ 0.01 and $<0.05$ ). The overall physicochemical results indicate that most of the clay samples will meet the requirements for some industrial applications with minimal processing.
\end{abstract}

\section{Keywords}

Clay, Kaolinite, Minerals, Physicochemical

\section{Introduction}

The clay minerals are basically composed of repeating tetrahedral and octahedral 
planar sheets. The tetrahedral and octahedral sheets form a polymeric alumino-silicate layer that is mostly crystalline in structure. Impurities such as $\mathrm{Fe}_{2} \mathrm{O}_{3}$, $\mathrm{TiO}_{2}, \mathrm{~K}_{2} \mathrm{O}$ and $\mathrm{Na}_{2} \mathrm{O}$ vary among clay samples from the different locations. Clay minerals share a basic set of structural and chemical characteristics, yet each clay mineral has its own unique set of properties that determine how it will interact with other chemical species [1].

The application of clay materials is influenced by their physical and chemical properties which determine their suitability for specific usage. The geographical location for each clay materials confer unique physico-chemical properties which ultimately determines the type of material produced and its application [2]. Specific physical and chemical properties of clays such as kaolin are also dependent on the environment of deposition, geological origin, geographic source and the material method at the end of processing [3]. The basic physical and chemical properties of clay materials are widely used in both academic and industrial fields. These properties may vary under the influences of both natural processes and human disturbances [4].

Clays are abundant and readily available. They also possess distinct adsorptive characteristics from one origin to another. The adsorption characteristics depend on the chemical and mineralogical composition as well as on textural, structural, and morphological properties [5]. Plasticity is also one of the most important clay properties that are related to different parameters. The most disaggregated clay minerals with major ionic exchange capability are more often plastic in nature. Montmorillonitic minerals are most plastic, than illitics, and least kaolinitics [6]. Clays and clay minerals such as montmorillonite, vermiculite, illite, kaolinite, and bentonite are widely used in process and petroleum industries, engineering and constructions, environmental remediation, ceramics and refractories, pharmaceuticals and agricultural sectors [7].

Nigeria has large quantity of clay minerals that are widely spread across the country. Some of the studies conducted on Nigerian clays are reported in many literatures [8] [9] [10] [11] [12]. This study evaluates the physical and chemical properties of the clay deposits in selected locations in Plateau State, Central Nigeria using statistical analysis.

\section{Materials and Methods}

\subsection{Study Site}

The study sites referenced in this research are all located in Plateau State, Central Nigeria. The deposit sites include RarinSho (RC), Major Porter (MP), Kwi (KC), Wereng Camp (WC) and Naraguta (NC). The study areas are bounded between latitudes $8^{\circ} 30 \mathrm{E}$ and $9^{\circ} 00 \mathrm{E}$ and longitudes $9^{\circ} 30 \mathrm{~N}$ and $10^{\circ} 00 \mathrm{~N}$ as shown in Figure 1. The clays at the deposit sites were classified as kaolinite and ball clays by Nigerian Mining Corporation (NMC). Geographically, the areas are characterized by uneven topographic profile with many hills. 


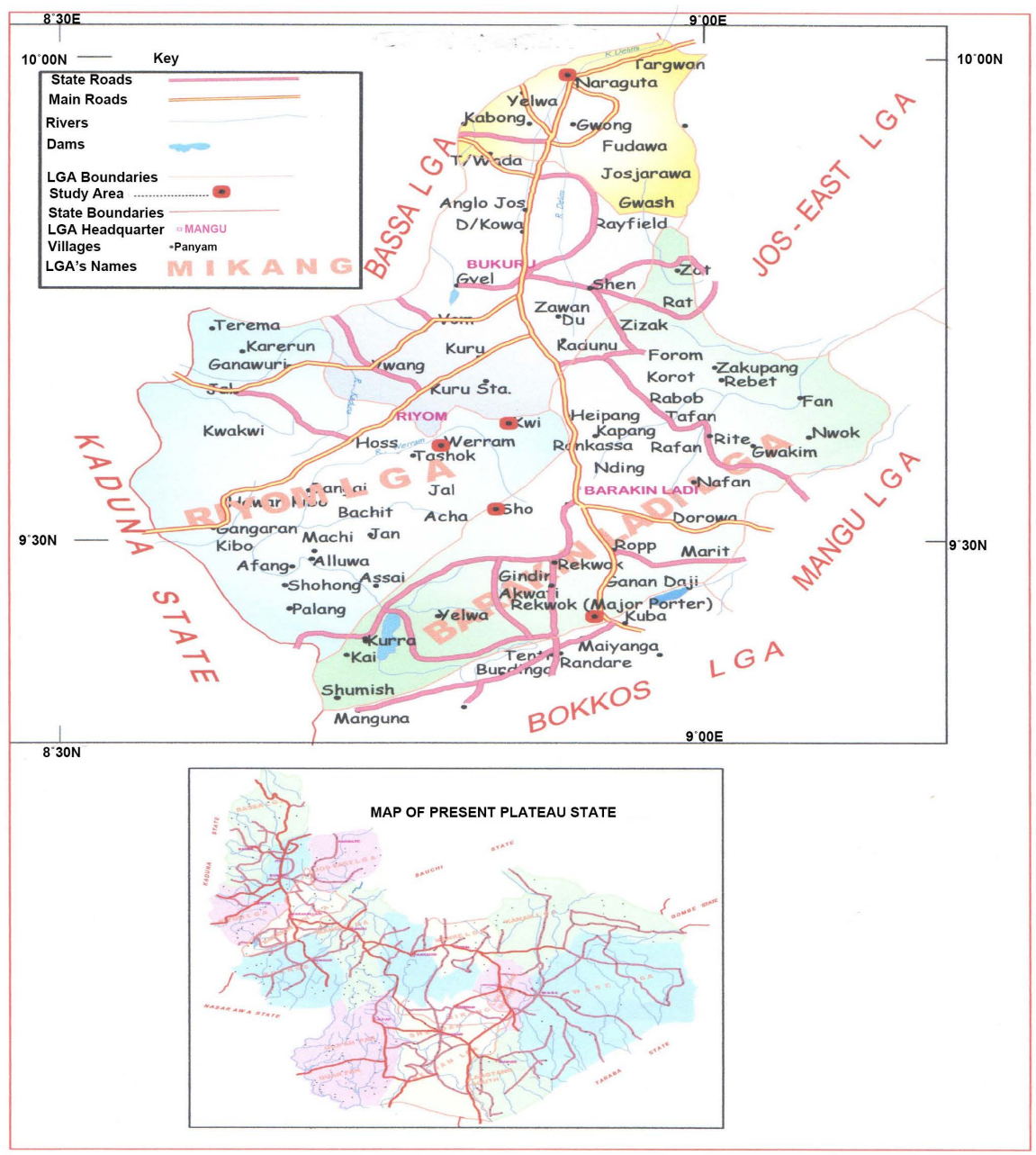

Figure 1. Map of the study sites [Adapted from Ministry of Land and Survey, Plateau State].

\subsection{Sample Collection and Determination}

The samples were obtained from underground local mines $10-20 \mathrm{~cm}$ beneath the soil surface. Ten different points within each deposit collected was by randomized sampling. In addition, $5 \mathrm{~kg}$ of fresh samples in lump form were obtained randomly from ten different points within each deposit from underground local mines pit at the depth of $10-20 \mathrm{~cm}$. The samples were air-dried for several days and crushed using a set of Denver crushers by Denver Equipment Company England. Each crushed sample was thoroughly mixed, coned and quartered. Two opposite composite representatives were obtained and consequently milled and pulverized. These were packaged in small polyethene bags as representatives of the samples for the required tests [11].

\subsection{Methods of Analysis}

\subsubsection{Chemical Analysis}

The chemical compositions of the pulverized samples were determined by Energy Dispersive X-ray Fluorescence (EDXRF) of the model PW4030 X-ray photome- 
ter that uses a rhodium anode tube. The sample film was placed firmly in a waxed and gold plated sample holder. The Energy Dispersive patterns were obtained with the help of a computer attached to the instrument and each compound recorded in percentage [13].

\subsubsection{Loss on Ignition}

Loss on ignition was determined according to the Lechler and Desiletes method, [14]. The samples were oven-dried at $110^{\circ} \mathrm{C}$. Then $1 \mathrm{~g}$ of the sample of clay was placed in preheated, cooled and pre-weighed silica crucibles and heated to $1000^{\circ} \mathrm{C}$ in a furnace for an hour. The crucibles and contents were removed, cooled in a desiccator to room temperature and weighed again. The loss in weight was calculated.

\subsection{Physical Analysis}

\subsubsection{Plasticity Index of Clay Samples}

The Atterberg plasticity method prescribed by [15] was used to calculate the plasticity index of the clay samples from their respective liquid and plastic limits determined.

\subsubsection{Particle-Size Analysis}

The particle size test was carried out by using the standard Hydrometer method [16]. $50 \mathrm{~g}$ of milled oven-dry clay was weighed into a $250 \mathrm{~cm}^{3}$ beakers and mixed with $100 \mathrm{~cm}^{3}$ calgon, then allowed to soak for 30 minutes. The mixed suspension was transferred into a sedimentation cylinder and filled up to mark point with distilled water.

The hydrometer was inserted into the mixture in the cylinder and the readings were taken after interval of 40 seconds twice. After 2 hours, another hydrometer reading and temperature were recorded. After 40 seconds and 2 hours, all the sand and silt particles would have settled and only clay will remain in suspension. The percentages of silt and clay were then calculated and the interpretation of result was made by using a textural triangle.

\subsubsection{Drying and Firing Shrinkage of Clays}

The clay drying and firing shrinkages were determined from brick bars prepared using a mechanical hydraulic press (model D-7064 Paul Weber) with its accessory moulds and the method adopted was [17].

\subsection{Statistical Analysis}

The statistical tools employed to carry out the data analysis of this study were the Microsoft 2010 Excel Package and Statistical Package for Social Sciences (SPSS) version 17.0 software. The Microsoft Excel was used to compute the mean and standard deviation generated results while the SPSS was employed to carry out the Analysis of variance (ANOVA) by Post-hoc tambane multiple comparisons F-test and Kristal Wallis T-test all at 5\% confidence level. This assisted in determining if significant differences exist in the average means of the concentration 
of the compounds from the different sample sites. The p-values that were equal to or less than 0.05 were considered significant.

\section{Correlation Coefficient}

Pearson correlation statistical tool was also used to establish if significant positive interrelationships exist between the chemical and physical parameters in each site of the clay samples. The strength of the variables on the scale of -1 (perfect inverse relation) through 0 (no relation) to +1 (perfect sympathetic relation) were determined at both confidence levels of 0.01 and 0.05 .

\section{Results and Discussion}

\subsection{Physicochemical Characteristics of the Clay Samples}

The results of the chemical and physical analysis of RarinSho (RC), Major Porter (MP), Wereng Camp (WC), Kwi (KC) and Naraguta (NC) clay samples are summarized in Tables 1-3 respectively. The chemical properties of the samples were determined statistically by analysis of variance (ANOVA) at $\left(\mathrm{F}_{8}, 36=52.40\right.$, $\mathrm{p}<0.05)$ and Krystal Wallis one sample t-test $\left(\mathrm{T}_{8}, 37.38, \mathrm{p}<0.01\right)$. The results of chemical analysis shows the different oxide components that indicate also the variations in the means of the concentrations of the compounds contained in the studied clay bodies.

The ANOVA in Table 1 showed that significant differences exist between the average means of the concentrations of the oxides of the different samples except for few minor constituents whose values are similar. The Krystal Wallis one sample t-test result of the randomized block design model used for major and trace oxides shown in Table 2 depicted that a greater degree of differences are observed from the p-values of silica $\left(\mathrm{SiO}_{2}\right)$ and alumina $\left(\mathrm{Al}_{2} \mathrm{O}_{3}\right)$. It shows that these oxides $\left(\mathrm{SiO}_{2}\right.$ and $\left.\mathrm{Al}_{2} \mathrm{O}_{3}\right)$ are significantly more, followed by the p-values of

Table 1. Chemical composition of oxides in the clays.

\begin{tabular}{cccccc}
\hline Oxides (\%) & $\begin{array}{c}\text { RarinSho } \\
\text { Clay (RC) }\end{array}$ & $\begin{array}{c}\text { Major Porter } \\
\text { Clay (MP) }\end{array}$ & $\begin{array}{c}\text { Wereng Camp } \\
\text { Clay (WC) }\end{array}$ & $\begin{array}{c}\text { Kwi Clay } \\
(\mathrm{KC})\end{array}$ & $\begin{array}{c}\text { Naraguta Clay } \\
(\mathrm{NC})\end{array}$ \\
\hline $\mathrm{SiO}_{2}$ & $62.26^{\mathrm{a}} \pm 0.14$ & $55.10^{\mathrm{b}} \pm 0.34$ & $50.15^{\mathrm{c}} \pm 0.19$ & $46.48^{\mathrm{d}} \pm 0.27$ & $41.20^{\mathrm{e}} \pm 0.04$ \\
$\mathrm{Al}_{2} \mathrm{O}_{3}$ & $29.44^{\mathrm{a}} \pm 0.11$ & $34.73^{\mathrm{b}} \pm 0.06$ & $37.15^{\mathrm{c}} \pm 0.14$ & $31.12^{\mathrm{d}} \pm 0.15$ & $17.25^{\mathrm{e}} \pm 0.12$ \\
$\mathrm{Fe}_{2} \mathrm{O}_{3}$ & $0.43^{\mathrm{a}} \pm 0.05$ & $1.39^{\mathrm{b}} \pm 0.11$ & $1.93^{\mathrm{c}} \pm 0.09$ & $5.54^{\mathrm{d}} \pm 0.11$ & $27.52^{\mathrm{e}} \pm 0.07$ \\
$\mathrm{TiO}_{2}$ & $0.05^{\mathrm{a}} \pm 0.02$ & $1.54^{\mathrm{b}} \pm 0.14$ & $2.82^{\mathrm{c}} \pm 0.03$ & $3.10^{\mathrm{c}} \pm 0.13$ & $3.28^{\mathrm{c}} \pm 0.03$ \\
$\mathrm{Na}_{2} \mathrm{O}$ & $0.13^{\mathrm{a}} \pm 0.02$ & $0.23^{\mathrm{b}} \pm 0.03$ & $0.08^{\mathrm{a}} \pm 0.02$ & $0.12^{\mathrm{a}} \pm 0.02$ & $1.17^{\mathrm{c}} \pm 0.05$ \\
$\mathrm{~K}_{2} \mathrm{O}$ & $2.19^{\mathrm{a}} \pm 0.04$ & $1.97^{\mathrm{a}} \pm 0.08$ & $0.13^{\mathrm{b}} \pm 0.02$ & $0.33^{\mathrm{c}} \pm 0.03$ & $3.10^{\mathrm{d}} \pm 004$ \\
$\mathrm{CaO}$ & $0.46^{\mathrm{a}} \pm 0.03$ & $0.43^{\mathrm{a}} \pm 0.03$ & $0.06^{\mathrm{b}} \pm 0.02$ & $0.23^{\mathrm{c}} \pm 0.03$ & $0.33^{\mathrm{d}} \pm 0.04$ \\
$\mathrm{MgO}$ & $0.33^{\mathrm{a}} \pm 0.03$ & $0.15^{\mathrm{b}} \pm 0.02$ & $0.07^{\mathrm{c}} \pm 0.01$ & $0.14^{\mathrm{b}} \pm 0.03$ & $0.57^{\mathrm{d}} \pm 0.03$ \\
$\mathrm{LOl}$ & $4.30^{\mathrm{a}} \pm 0.16$ & $5.22^{\mathrm{b}} \pm 0.16$ & $8.38^{\mathrm{c}} \pm 0.09$ & $12.43^{\mathrm{d}} \pm 0.08$ & $5.13^{\mathrm{c}} \pm 0.09$ \\
\hline
\end{tabular}

a-d = Mean average values within a row with different superscripts are significantly different at $5 \%$ level and $\mathrm{a}-\mathrm{a}=$ Mean average values within a row with the same small letter superscripts are not significantly different at $5 \%$ level. 
Table 2. Kristal wallis one-sample t-test.

\begin{tabular}{ccccc}
\hline Oxide & $\mathbf{t}$ & $\mathrm{df}$ & P-Value & Mean \\
\hline $\mathrm{SiO}_{2}$ & 14.25 & 4 & $0.000^{*}$ & 51.00 \\
$\mathrm{Al}_{2} \mathrm{O}_{3}$ & 8.709 & 4 & $0.001^{*}$ & 30.00 \\
$\mathrm{Fe}_{2} \mathrm{O}_{3}$ & 1.44 & 4 & 0.223 & 7.36 \\
$\mathrm{TiO}_{2}$ & 4.17 & 4 & $0.014^{*}$ & 2.14 \\
$\mathrm{Na}_{2} \mathrm{O}$ & 1.67 & 4 & 0.17 & 0.35 \\
$\mathrm{~K}_{2} \mathrm{O}$ & 2.74 & 4 & $0.05^{*}$ & 1.53 \\
$\mathrm{CaO}$ & 4.61 & 4 & $0.001^{*}$ & 0.24 \\
$\mathrm{MgO}$ & 2.63 & 4 & 0.06 & 0.23 \\
$\mathrm{LOI}$ & 4.71 & 4 & $0.009^{*}$ & 7.09 \\
\hline
\end{tabular}

* = Significantly different and $\mathrm{P}=$ Probability value.

Table 3. Physical properties of the clay samples.

\begin{tabular}{|c|c|c|c|c|c|c|c|c|c|}
\hline \multirow{2}{*}{ Sample Clays } & \multirow{2}{*}{$\mathrm{pH}$} & \multicolumn{3}{|c|}{ Particle Size (\%) } & \multicolumn{3}{|c|}{ Plasticity (\%) } & \multicolumn{2}{|c|}{ Shrinkage (\%) } \\
\hline & & Clay & Silt & Quartz & LL & PL & PI & Drying & Firing \\
\hline RarinSho Clay & $6.0 \pm 0.08$ & $67.88 \pm 0.09$ & $24.00 \pm 0.11$ & $8.12 \pm 0.08$ & $57.30 \pm 0.32$ & $25.45 \pm 0.08$ & $33.68 \pm 0.23$ & $1.10 \pm 0.09$ & $1.65 \pm 0.07$ \\
\hline Major Porter Clay & $6.1 \pm 0.11$ & $73.88 \pm 1.00$ & $18.00 \pm 0.00$ & $8.12 \pm 1.00$ & $45.38 \pm 0.28$ & $29.48 \pm 0.28$ & $15.90 \pm 0.00$ & $1.10 \pm 0.00$ & $2.23 \pm 0.55$ \\
\hline $\begin{array}{c}\text { Wereng Camp } \\
\text { Clay }\end{array}$ & $5.60 \pm 0.13$ & $91.88 \pm 1.00$ & $6.00 \pm 0.00$ & $2.12 \pm 1.00$ & $61.15 \pm 0.95$ & $44.05 \pm 0.85$ & $17.20 \pm 0.00$ & $2.23 \pm 0.03$ & $4.99 \pm 0.56$ \\
\hline Kwi Clay & $5.2 \pm 0.13$ & $84.88 \pm 4.00$ & $14.00 \pm 2.00$ & $4.12 \pm 1.00$ & $63.90 \pm 0.4$ & $28.60 \pm 0.00$ & $33.30 \pm 0.4$ & $1.14 \pm 0.04$ & $2.40 \pm 0.00$ \\
\hline Naraguta Clay & $6.4 \pm 0.29$ & $49.88 \pm 3.00$ & $43.00 \pm 3.00$ & $7.12 \pm 0.00$ & $48.03 \pm 1.48$ & $23.50 \pm 0.8$ & $24.53 \pm 2.28$ & $2.22 \pm 0.02$ & $3.30 \pm 0.00$ \\
\hline
\end{tabular}

LL = Liquid Limit; PL = Plasticity Limit; PI = Plastic Index.

calcium oxide $(\mathrm{CaO})$ and loss on ignition (LOI). The high amounts of $\mathrm{SiO}_{2}$, $\mathrm{Al}_{2} \mathrm{O}_{3}$ and LOI define the clay samples as hydrated alumino-silicate type of minerals [17]. This is attributed to the fact that kaolin clays are principally composed of $\mathrm{SiO}_{2}, \mathrm{Al}_{2} \mathrm{O}_{3}$ and water, which have a chemical composition of $\mathrm{Al}_{2} \mathrm{Si}_{2} \mathrm{O}_{5}(\mathrm{OH})_{4}$, also represented as $\mathrm{Al}_{2} \mathrm{O}_{3} \cdot 2 \mathrm{SiO}_{2} \cdot 2 \mathrm{H}_{2} \mathrm{O}$.

The results of the Pearson bivariate correlation coefficient determined between the chemical and physicalproperties of the clay samples in Tables 4-8 showed very significant, strong and positive correlations. Most of the correlation values fall within the range of 0.900 and above but less than unity in all the samples.

\subsection{Correlation Associations between the Clay Parameters}

Interrelationships in clay chemical and physical properties were assessed for each sample site by Pearson Bivariate correlation analysis. Multiple and very strong significant correlations were observed and selected. The correlations determined for RarinSho clay sample shown in Table 4 were highly significant. Very high significant interactions were observed between silt and PL $(r=0.953)$, $\mathrm{K}_{2} \mathrm{O}$ and $\mathrm{CaO}(\mathrm{r}=0.942)$, Quartz and $\mathrm{pH}(\mathrm{r}=0.925)$, and $\mathrm{Al}_{2} \mathrm{O}_{3}$ and $\mathrm{PL}(\mathrm{r}=$ 
Table 4. Pearson bivariate correlation for RC sample site.

\begin{tabular}{|c|c|c|c|c|c|c|c|c|c|c|c|c|c|c|c|c|c|}
\hline & & $\mathrm{SiO}_{2}$ & $\mathrm{Al}_{2} \mathrm{O}_{3}$ & $\mathrm{Fe}_{2} \mathrm{O}_{3}$ & $\mathrm{TiO}_{2}$ & $\mathrm{Na}_{2} \mathrm{O}$ & $\mathrm{K}_{2} \mathrm{O}$ & $\mathrm{CaO}$ & $\mathrm{MgO}$ & LOI & Clay & Silt & Quartz & LL & PL & PI & $\mathrm{pH}$ \\
\hline $\mathrm{SiO}_{2}$ & $\mathrm{R}$ & 1 & & & & & & & & & & & & & & & \\
\hline $\mathrm{Al}_{2} \mathrm{O}_{3}$ & $\mathrm{R}$ & -0.081 & 1 & & & & & & & & & & & & & & \\
\hline $\mathrm{Fe}_{2} \mathrm{O}_{3}$ & $\mathrm{R}$ & -0.542 & -0.457 & 1 & & & & & & & & & & & & & \\
\hline $\mathrm{TiO}_{2}$ & $\mathrm{R}$ & 0.566 & -0.572 & -0.438 & 1 & & & & & & & & & & & & \\
\hline $\mathrm{Na}_{2} \mathrm{O}$ & $\mathrm{R}$ & 0.427 & -0.683 & -0.114 & $0.896\left(^{*}\right)$ & 1 & & & & & & & & & & & \\
\hline $\mathrm{K}_{2} \mathrm{O}$ & $\mathrm{R}$ & -0.609 & 0.23 & 0.706 & -0.768 & -0.408 & 1 & & & & & & & & & & \\
\hline $\mathrm{CaO}$ & $\mathrm{R}$ & -0.702 & 0.339 & 0.678 & $-0.923\left(^{*}\right)$ & -0.67 & $\left.0.9422^{*}\right)$ & 1 & & & & & & & & & \\
\hline $\mathrm{MgO}$ & $\mathrm{R}$ & -0.571 & 0.604 & -0.325 & -0.379 & -0.605 & -0.013 & 0.209 & 1 & & & & & & & & \\
\hline LOI & $\mathrm{R}$ & -0.541 & 0.477 & -0.399 & -0.085 & -0.21 & -0.027 & 0.049 & 0.875 & 1 & & & & & & & \\
\hline Clay & $\mathrm{R}$ & 0.402 & 0.764 & -0.804 & 0.05 & -0.071 & -0.17 & -0.223 & 0.258 & 0.377 & 1 & & & & & & \\
\hline Silt & $\mathrm{R}$ & 0.141 & 0.749 & -0.044 & -0.655 & -0.558 & 0.524 & 0.524 & -0.016 & -0.16 & 0.543 & 1 & & & & & \\
\hline Quartz & $\mathrm{R}$ & 0.024 & 0.791 & -0.431 & -0.247 & -0.169 & 0.317 & 0.21 & 0.268 & 0.445 & 0.866 & 0.672 & 1 & & & & \\
\hline LL & $\mathrm{R}$ & -0.533 & -0.229 & 0.785 & -0.33 & 0.111 & 0.848 & 0.663 & -0.303 & -0.112 & -0.367 & 0.122 & 0.117 & 1 & & & \\
\hline PL & $\mathrm{R}$ & 0.031 & $0.903\left(^{*}\right)$ & -0.219 & -0.641 & -0.597 & 0.468 & 0.487 & 0.24 & 0.14 & 0.699 & $0.953\left(^{*}\right)$ & 0.822 & 0.043 & 1 & & \\
\hline PI & $\mathrm{R}$ & 0.589 & 0.06 & -0.819 & 0.558 & 0.139 & $\left.-0.9511^{*}\right)$ & -0.828 & 0.203 & 0.123 & 0.344 & -0.3 & -0.156 & $\left.-0.966^{(* *}\right)$ & -0.213 & 1 & \\
\hline $\mathrm{pH}$ & $\mathrm{R}$ & -0.345 & 0.743 & -0.251 & -0.365 & -0.254 & 0.462 & 0.389 & 0.484 & 0.671 & 0.676 & 0.504 & $0.925\left(^{*}\right)$ & 0.282 & 0.704 & -0.319 & 1 \\
\hline
\end{tabular}

${ }^{*}$ Correlation is significant at the 0.05 level (2-tailed). ${ }^{*}$ Correlation is significant at the 0.01 level (2-tailed) $\mathrm{R}=$ Pearson correlation.

$0.903)$ all at $(\mathrm{p}<0.05)$. There was also a moderate level of significant correlation between $\mathrm{TiO}_{2}$ and $\mathrm{Na}_{2} \mathrm{O}(\mathrm{r}=0.896)$ at $(\mathrm{p}<0.05)$. The chemical analysis of this sample showed that the value of $\mathrm{SiO}_{2}$ was much higher than normal, chiefly due to the quantity of silt and quartz present from its size analysis. The association also indicates that the content of silt and $\mathrm{Al}_{2} \mathrm{O}_{3}$ contribute positively to the increase of the plastic limit of the sample. The site also indicates that the increase in the concentration of $\mathrm{K}_{2} \mathrm{O}$ resulted to the slight rise of that of $\mathrm{CaO}$.

Similarly, some interrelationships occurred between the physical and chemical properties of Major Porter clay sample. The most positive significant correlations amongst the oxides concentration was observed between $\mathrm{Fe}_{2} \mathrm{O}_{3}$ and $\mathrm{TiO}_{2}(\mathrm{r}$ $=0.995)$ at $(\mathrm{p}<0.01)$ shown in Table 5. Significant correlations were also observed between $\mathrm{Fe}_{2} \mathrm{O}_{3} / \mathrm{TiO}_{2}$ and clay $(\mathrm{r}=0.977,0.972)$, also at $(\mathrm{p}<0.01)$, and $\mathrm{K}_{2} \mathrm{O}$ and Clay $(\mathrm{r}=0.952)$ at $(\mathrm{p}<0.05)$. Clay and PI $(\mathrm{r}=0.950)$ also associated at $(\mathrm{p}<0.05)$. There was also a strong double significant association between $\mathrm{Fe}_{2} \mathrm{O}_{3} / \mathrm{TiO}_{2}$ and the plastic index of the sample at $(\mathrm{r}=0.958 ; \mathrm{p}<0.05)$. The sample in this site was notably observed to contain an appreciable amount of $\mathrm{Fe}_{2} \mathrm{O}_{3}$ and $\mathrm{SiO}_{2}$. The low LOI value of the sample is attributed to the amount of quartz obtained from its size analysis.

Table 6 shows a very strong significant interactions between $\mathrm{Fe}_{2} \mathrm{O}_{3}$ and clay $(\mathrm{r}$ $=0.967, \mathrm{p}<0.01), \mathrm{Al}_{2} \mathrm{O}_{3}$ and $\mathrm{TiO}_{2}(\mathrm{r}=0.916)$, and $\mathrm{SiO}_{2}$ and $\mathrm{TiO}_{2}(\mathrm{r}=0.900)$ at $(\mathrm{p}$ $<0.05)$ in Wereng Camp clay deposit. Also observed was the significant 
Table 5. Pearson bivariate correlation for MP sample site.

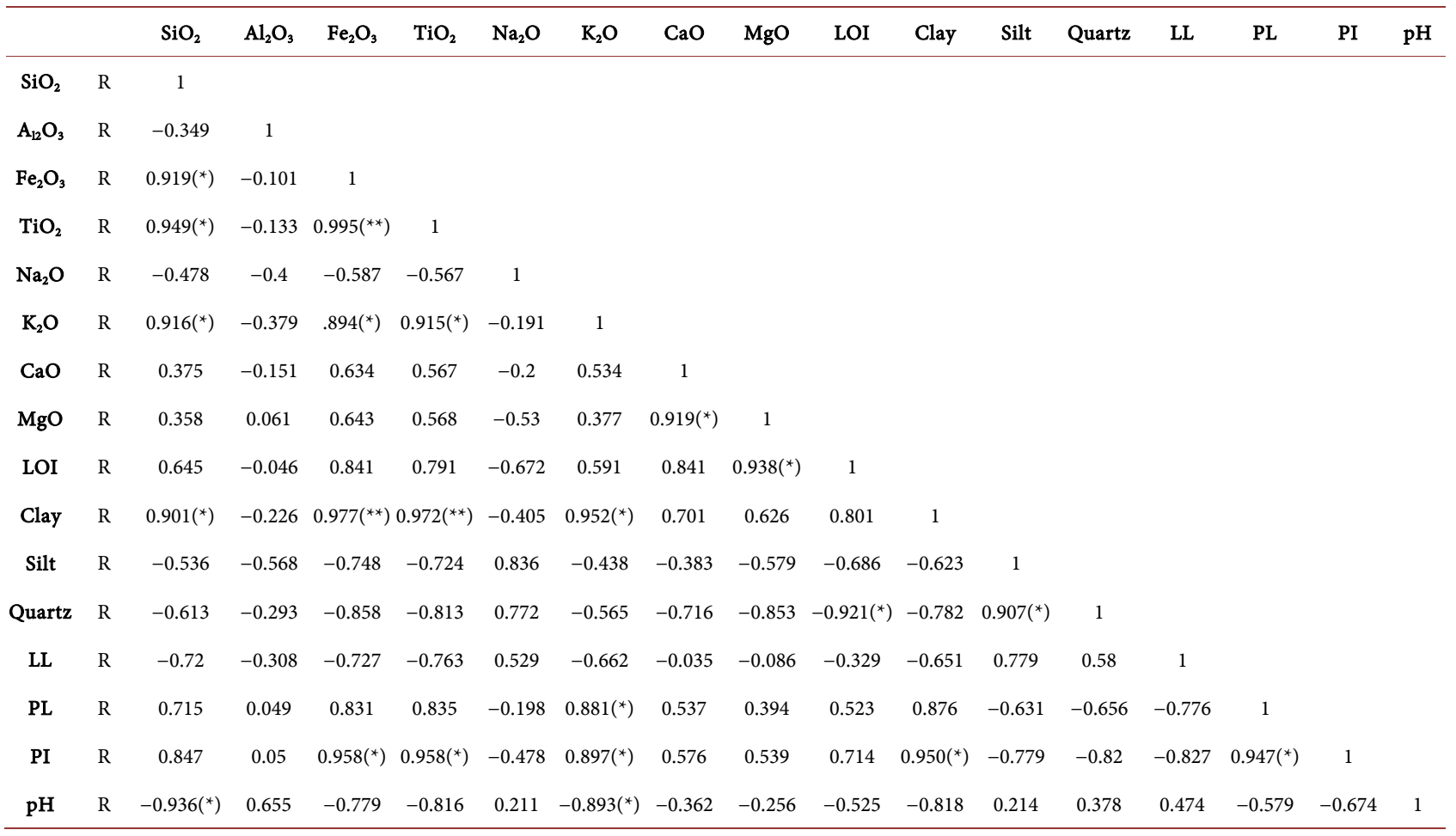

${ }^{*}$ Correlation is significant at the 0.05 level $\left(2\right.$-tailed). ${ }^{* *}$ Correlation is significant at the 0.01 level (2-tailed). $\mathrm{R}=$ Pearson Correlation.

Table 6. Pearson bivariate correlation for WC sample site.

\begin{tabular}{|c|c|c|c|c|c|c|c|c|c|c|c|c|c|c|c|c|c|}
\hline & & $\mathrm{SiO}_{2}$ & $\mathrm{Al}_{2} \mathrm{O}_{3}$ & $\mathrm{Fe}_{2} \mathrm{O}_{3}$ & $\mathrm{TiO}_{2}$ & $\mathrm{Na}_{2} \mathrm{O}$ & $\mathrm{K}_{2} \mathrm{O}$ & $\mathrm{CaO}$ & $\mathrm{MgO}$ & LOI & Clay & Silt & Quartz & LL & PL & PI & $\mathrm{pH}$ \\
\hline $\mathrm{SiO}_{2}$ & $\mathrm{R}$ & 1 & & & & & & & & & & & & & & & \\
\hline $\mathrm{Al}_{2} \mathrm{O}_{3}$ & $\mathrm{R}$ & $0.898\left(^{*}\right)$ & 1 & & & & & & & & & & & & & & \\
\hline $\mathrm{Fe}_{2} \mathrm{O}_{3}$ & $\mathrm{R}$ & 0.596 & 0.375 & 1 & & & & & & & & & & & & & \\
\hline $\mathrm{TiO}_{2}$ & $\mathrm{R}$ & $0.900\left(^{*}\right)$ & $0.916\left(^{*}\right)$ & 0.416 & 1 & & & & & & & & & & & & \\
\hline $\mathrm{Na}_{2} \mathrm{O}$ & $\mathrm{R}$ & 0.785 & 0.754 & 0.858 & 0.742 & 1 & & & & & & & & & & & \\
\hline $\mathrm{K}_{2} \mathrm{O}$ & $\mathrm{R}$ & -0.429 & -0.13 & -0.416 & 0 & -0.163 & 1 & & & & & & & & & & \\
\hline $\mathrm{CaO}$ & $\mathrm{R}$ & -0.836 & -0.532 & -0.837 & -0.593 & -0.727 & 0.685 & 1 & & & & & & & & & \\
\hline $\mathrm{MgO}$ & $\mathrm{R}$ & -0.007 & -0.224 & -0.169 & 0.15 & -0.283 & 0.173 & -0.079 & 1 & & & & & & & & \\
\hline Clay & $\mathrm{R}$ & 0.506 & 0.235 & $0.967\left(^{* *}\right)$ & 0.235 & 0.731 & -0.591 & -0.834 & -0.224 & -0.124 & 1 & & & & & & \\
\hline Silt & $\mathrm{R}$ & 0.782 & 0.823 & 0.115 & $.942\left(^{*}\right)$ & 0.475 & 0.099 & -0.406 & 0.343 & 0.756 & -0.063 & 1 & & & & & \\
\hline Quartz & $\mathrm{R}$ & -0.698 & -0.813 & 0.148 & -0.73 & -0.242 & 0.147 & 0.253 & -0.011 & -0.398 & 0.231 & -0.83 & 1 & & & & \\
\hline LL & $\mathrm{R}$ & -0.222 & 0.102 & -0.023 & -0.224 & 0.158 & 0.203 & 0.379 & $-.926\left(^{*}\right)$ & -0.04 & -0.02 & -0.37 & 0.12 & 1 & & & \\
\hline PL & $\mathrm{R}$ & -0.308 & -0.254 & 0.469 & -0.357 & 0.314 & 0.128 & 0.065 & -0.585 & -0.118 & 0.483 & -0.62 & 0.721 & 0.647 & 1 & & \\
\hline PI & $\mathrm{R}$ & 0.044 & 0.083 & -0.555 & -0.133 & -0.474 & -0.456 & 0.13 & -0.14 & -0.479 & -0.418 & 0.049 & -0.557 & -0.021 & -0.629 & 1 & \\
\hline $\mathrm{pH}$ & $\mathrm{R}$ & -0.292 & -0.004 & -0.307 & -0.39 & -0.167 & -0.036 & 0.454 & $-.882\left(^{*}\right)$ & -0.356 & -0.219 & -0.433 & -0.033 & $.882\left(^{*}\right)$ & 0.339 & 0.433 & 1 \\
\hline
\end{tabular}

${ }^{\star}$ Correlation is significant at the 0.05 level $\left(2-\right.$ tailed). ${ }^{*}$ Correlation is significant at the 0.01 level $(2-$ tailed). $\mathrm{R}=$ Pearson correlation. 
Table 7. Pearson bivariate correlation for KC sample site.

\begin{tabular}{|c|c|c|c|c|c|c|c|c|c|c|c|c|c|c|c|c|c|}
\hline & & $\mathrm{SiO}_{2}$ & $\mathrm{Al}_{2} \mathrm{O}_{3}$ & $\mathrm{Fe}_{2} \mathrm{O}_{3}$ & $\mathrm{TiO}_{2}$ & $\mathrm{Na}_{2} \mathrm{O}$ & $\mathrm{K}_{2} \mathrm{O}$ & $\mathrm{CaO}$ & $\mathrm{MgO}$ & LOI & Clay & Silt & Quartz & LL & PL & PI & $\mathrm{pH}$ \\
\hline $\mathrm{SiO}_{2}$ & $\mathrm{R}$ & 1 & & & & & & & & & & & & & & & \\
\hline $\mathrm{Al}_{2} \mathrm{O}_{3}$ & $\mathrm{R}$ & 0.641 & 1 & & & & & & & & & & & & & & \\
\hline $\mathrm{Fe}_{2} \mathrm{O}_{3}$ & $\mathrm{R}$ & -0.367 & -0.027 & 1 & & & & & & & & & & & & & \\
\hline $\mathrm{TiO}_{2}$ & $\mathrm{R}$ & 0.225 & 0.312 & -0.425 & 1 & & & & & & & & & & & & \\
\hline $\mathrm{Na}_{2} \mathrm{O}$ & $\mathrm{R}$ & 0.471 & 0.171 & 0.548 & -0.374 & 1 & & & & & & & & & & & \\
\hline $\mathrm{K}_{2} \mathrm{O}$ & $\mathrm{R}$ & 0.309 & 0.293 & 0.049 & -0.748 & 0.31 & 1 & & & & & & & & & & \\
\hline $\mathrm{CaO}$ & $\mathrm{R}$ & 0.477 & 0.663 & -0.32 & -0.221 & -0.075 & 0.794 & 1 & & & & & & & & & \\
\hline $\mathrm{MgO}$ & $\mathrm{R}$ & 0.168 & 0.098 & 0.493 & $-.884\left(^{*}\right)$ & 0.671 & 0.85 & 0.4 & 1 & & & & & & & & \\
\hline LOI & $\mathrm{R}$ & -0.07 & 0.003 & -0.838 & 0.349 & $-.890\left(^{*}\right)$ & -0.052 & 0.375 & -0.546 & 1 & & & & & & & \\
\hline Clay & $\mathrm{R}$ & -0.314 & 0.109 & 0.355 & 0.659 & -0.145 & -0.815 & -0.582 & -0.61 & -0.195 & 1 & & & & & & \\
\hline Silt & $\mathrm{R}$ & -0.49 & -0.768 & -0.48 & -0.244 & -0.595 & -0.018 & -0.128 & -0.192 & 0.588 & -0.428 & 1 & & & & & \\
\hline Quarz & $\mathrm{R}$ & -0.542 & -0.185 & 0.335 & 0.559 & -0.266 & $-.882\left(^{*}\right)$ & -0.737 & -0.653 & -0.129 & $0.953\left(^{*}\right)$ & -0.159 & 1 & & & & \\
\hline LL & $\mathrm{R}$ & -0.285 & -0.804 & 0.02 & 0.1 & 0.103 & -0.623 & $-.893\left(^{*}\right)$ & -0.316 & -0.236 & 0.2 & 0.381 & 0.394 & 1 & & & \\
\hline PL & $\mathrm{R}$ & $-.926\left(^{\star}\right)$ & -0.769 & 0.476 & -0.189 & -0.219 & -0.471 & -0.754 & -0.168 & -0.193 & 0.403 & 0.401 & 0.637 & 0.582 & 1 & & \\
\hline PI & $\mathrm{R}$ & -0.657 & -0.27 & 0.608 & 0.268 & -0.08 & -0.721 & -0.762 & -0.377 & -0.363 & 0.877 & -0.189 & $0.944\left(^{*}\right)$ & 0.394 & 0.771 & 1 & \\
\hline $\mathrm{pH}$ & $\mathrm{R}$ & $-.930\left(^{*}\right)$ & -0.811 & 0.357 & -0.139 & -0.316 & -0.506 & -0.751 & -0.25 & -0.079 & 0.374 & 0.498 & 0.626 & 0.612 & $\left.0.9911^{* *}\right)$ & 0.728 & 1 \\
\hline
\end{tabular}

${ }^{*}$ Correlation is significant at the 0.05 level (2-tailed). ${ }^{* *}$ Correlation is significant at the 0.01 level (2-tailed). $\mathrm{R}=$ Pearson Correlation.

Table 8. Pearson bivariate correlation for NC sample site.

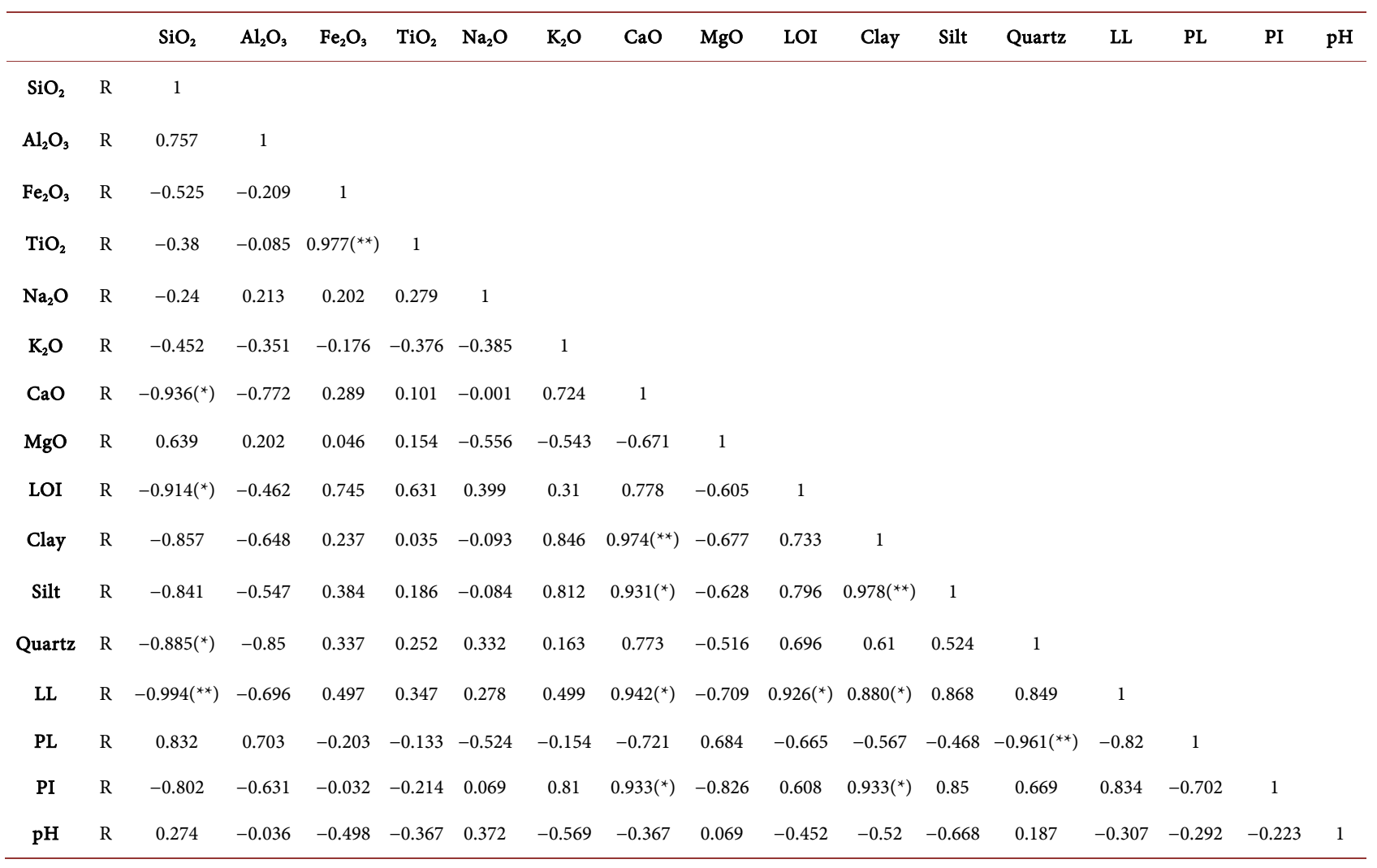

${ }^{*}$ Correlation is significant at the 0.05 level (2-tailed); ${ }^{*}$ Correlation is significant at the 0.01 level (2-tailed); $\mathrm{R}=$ Pearson Correlation. 
correlation between $\mathrm{TiO}_{2}$ and silt $(\mathrm{r}=0.942 ; \mathrm{p}<0.05)$. The significant strong association of $\mathrm{Fe}_{2} \mathrm{O}_{3}$ and $\mathrm{TiO}_{2}$ can be explained from their appreciable quantities as impurities in the sample. The high concentration of $\mathrm{TiO}_{2}$ in the sample is due to its close association to the small quantity of the silt.

The most significant and very strong positive relationship amongst the properties in Kwi clay sample was between PL and $\mathrm{pH}(\mathrm{r}=0.991, \mathrm{p}<0.01)$. There was also a strong correlation between clay and quartz $(r=0.953, p<0.05)$ and between quartz and PI $(r=0.944 ; \mathrm{p}<0.05)$ as shown in Table 7. The sample also indicated numerous negative correlations at different strengths but not considered. The interrelationship in this deposit has shown that the sample has the lowest $\mathrm{pH}$ in Table 3 contributing to the positive increase of its PL value.

Table 8 reveals many positive correlations in Naraguta clay deposit. The highest significant relationship was between clay and silt $(\mathrm{r}=0.978), \mathrm{Fe}_{2} \mathrm{O}_{3}$ and $\mathrm{TiO}_{2}(\mathrm{r}=0.977)$, CaOand clay $(\mathrm{r}=0.974)$ all at $(\mathrm{p}<0.01)$. There was also a positive significant relationship between CaOand LL $(r=0.942)$. Other significant associations were found between $\mathrm{CaO}$, clay and PI of the sample at $(\mathrm{r}=0.933$; $\mathrm{p}$ $<0.05)$. Also strongly significant was the correlation between LOI and LL ( $\mathrm{r}=$ 0.926; $\mathrm{p}<0.05$ ). The high concentrations of $\mathrm{Fe}_{2} \mathrm{O}_{3}$ and $\mathrm{TiO}_{2}$ at $28 \%$ and $3 \%$ respectively indicate a very high level of impurities. The moderate values of LOI, LL, and PL observed could all be attributed to the very high amount of $\mathrm{SiO}_{2}$ and quartz.

\section{Conclusion}

The very strong and high positive correlations in the clay properties reveal the amount and level of the oxide concentrations which consequently influence their physical properties and thereby their quality and functions. The results of the chemical and physical properties show that all the samples are suitable for various industrial applications.

\section{Conflicts of Interest}

The authors declare no conflicts of interest regarding the publication of this paper.

\section{References}

[1] Attah, E.L. and Oden, I.M. (2010) Physico-Chemical Properties and Industrial Potential of Some Clay Deposits in Calabar Area, South Eastern Nigeria. Global Journal of Environmental Sciences, 9, 39-49.

https://www.ajol.info/index.php/gjes/article/viewFile/79207/69522

[2] Asamoah, R.B., Nyankson, E., Annan, E., Agyei-Tuffour, B., Efavi, J.K., Kan-Dapaah, K., Apalangya, V.A., Damoah, L.N.W., Dodoo-Arhin, D., Tiburu, E.K., Kwofie, S.K., Onwona-Agyeman, B. and Yaya, A. (2018) Industrial Applications of Clay Materials from Ghana (A Review). Oriental Journal of Chemistry, 34, 1719-1734. https://doi.org/10.13005/ojc/340403

[3] Akinyemi, S.A., Ogunniyi, S.O., Ojo, A.O., Gitari, W.M., Momoh, A., Akinola, 
O.O., Talabi, O., Afolagboye, L.O., Olaolorun, O.A. and Ayodele, O.S. (2014) Mineralogy, Physicochemical Characteristics and Industrial Potential of Some Residual Clay Deposits within Ekiti State, Southwestern Nigeria. Journal of Environment and Earth Science, 4, 70-88.

https://www.iiste.org/Journals/index.php/JEES/article/view/15894/16252

[4] Lu, M.Y., Jin, F.Y., Shen, L.S., Yu, F. and Zhang, J. (2015) Statistical Analysis on Physical Properties of Shanghai Soft Clay. Geotechnical Engineering Journal of the SEAGS \& AGSSEA, 46, 31-36.

[5] Jock, A.A., Zaini, M.A.A., Surajudeen, A., El-Nafaty, U.A. and Aroke, U.O. (2016) Physicochemical Characteristics of Surface Modified Dijah-Monkin Bentonite. Particulate Science and Technology, 36, 287-297. https://doi.org/10.1080/02726351.2016.1245689

[6] Jongs, S.L., Jock, A.A., Ekanem, E.O. and Jauro, A. (2018) Investigating the Industrial Potentials of Some Selected Nigerian Clay Deposits. Journal of Minerals and Materials Characterization and Engineering, 6, 569-586. https://doi.org/10.4236/jmmce.2018.66041

[7] Alexander, J.A., Zaini, M.A.A., Surajudeen, A., El-Nafaty, U. and Aroke, U.O. (2018) Surface Modification of Low-Cost Bentonite Adsorbents-A Review. Particulate Science and Technology, 37, 534-545. https://doi.org/10.1080/02726351.2018.1438548

[8] Jock, A.A., Ayeni, F.A., Ahmed, A.S. and Sullayman, U.A. (2013) Evaluation of Refractory Properties of Nigerian Ozanagogo Clay Deposit. Journal of Minerals and Materials Characterization and Engineering, 1, 321-325. https://doi.org/10.4236/jmmce.2013.16048

[9] Jock, A.A., Zaini, M.A.A., Surajudeen, A., El-Nafaty, U. and Aroke, U.O. (2016) Insight into Kinetics and Thermodynamics Properties of Multicomponent Lead (II), Cadmium (II) and Manganese (II) Adsorption onto Dijah-Monkin Bentonite Clay. Particulate Science and Technology, 36, 569-577. https://doi.org/10.1080/02726351.2016.1276499

[10] Talabi, O.A., Ademilua, L.O. and Akinola, O.O. (2012) Compositional Features and Industrial Application of Ikere Kaolinite, South Western Nigeria. Research Journal in Engineering and Applied Sciences, 1, 327-333.

http://citeseerx.ist.psu.edu/viewdoc/download?doi=10.1.1.682.5424\&rep=rep1\&type $=\mathrm{pdf}$

[11] Osabor, N.V., Okafor, C.P., Abe, K.A. and Ayi, A.A. (2009) Characterization of Odukpani, South Eastern Nigeria. African Journal of Pure and Applied Chemistry, 3, 79-85. https://academicjournals.org/journal/AJPAC/article-abstract/936D2921664

[12] Irabor, P.S.A. (2002) Physical and Chemical Investigation on Some Nigerian Kaolinite Clays for Use in the Ceramics and Allied Industries. Nigerian Journal of Engineering Research and Development, 1, 54-59.

[13] Jock, A.A., Ayeni, F.A., Jongs, L.S. and Kangpe, N.S. (2013) Development of Refractory Bricks from Nigerian Nafuta Clay Deposit. International Journal of Materials Methods and Technologies, 1, 189-195. http://ijmmt.com/IJMMT_Vol.\%201,\%20No.\%2010,\%20November\%202013/DEVE LOPMENT.pdf

[14] American Society for Testing and Materials (2010) 10 Standard Tests Methods for Liquid Limit, Plastic Limit and Plasticity Index of Soils.

[15] Ibitoye, A.A. (2008) Laboratory Manual on Basic Soil Analysis. 3rd Edition. 
[16] American Society for Testing and Materials (1990) Linear Shrinkage and Coefficient of Thermal Expansion of Chemical Resistance Mortars Grouts.

[17] Hassan, S.B. (2005) Modern Refractories-Production, Properties, Testing and Applications. Timo Press, Zaria. 